\title{
Gorontalo
}

Journal of Government and Political Studies

Volume 4 - NO. 1 - April 2021

P-ISSN: 2614-2120 E-ISSN: 2614-2104

\section{Happy Elderly Through Elderly School: Collaboration in Empowering Elderly in Bandung City}

\author{
Rike Anggun Artisa, \\ Cintantya Andhita Dara Kirana \\ Politeknik STIA LAN Bandung \\ Jalan Hayam Wuruk No. 34-38, Kota Bandung \\ rikeanggunartisa@gmail.com
}

Received: O2nd February 2021; Revised: 07th March 2021;

Accepted: 08th March 2021;

\begin{abstract}
The development of a paradigm in which the government no longer the only actor in charge of public affairs opens greater opportunities for the elderly to get attention. The elderly become a group with vulnerable conditions, from physical, social, mental, and spiritual aspects. The elderly school was formed through collaboration as a form of caring for the elderly in Bandung City. The elderly school is intended to improve the knowledge and behavior of the elderly towards health, increase the index of happiness, improve the quality of life and productivity, and increase independence from physical, psychological, social, and spiritual aspects. The purpose of this study is to identify and analyze the factors that drive collaboration, the collaborative process, and the benefits of collaboration. The research method used is a qualitative research method with a descriptive approach. The results show that the collaboration in the elderly school program is driven by the same goals and interests related to empowering the elderly, having appropriate resources with their fields and functions, and getting benefits from their involvement. Then, the collaborative process begins with a dialogue to build trust among stakeholders to build commitment to this program. Collaboration in senior schools is not only beneficial for the elderly but also for the actors involved.
\end{abstract}

Keywords: School; Elderly; Collaboration; Empowerment

\section{INTRODUCTION}

The elderly are one of the groups of people who have reached the age of 60 (Law No.13 / 1998) whose existence needs attention because the elderly are in a vulnerable condition. The problems experienced by the elderly include health, economic, social, and environmental problems (Seftiani, 2018). This is a serious challenge in line with the increasing number of elderly people. Like two sides of a coin, an increase in the number of elderly people is a good thing because life expectancy is increasing, but it becomes a challenge related to efforts to realize a quality elderly life.

The life expectancy of the elderly in Bandung City in 2019 is 74.4 years. This figure continues to increase from 2018 and 2017, respectively 74 years and 73 years (Pikiran Rakyat, 24/8/2020). Bandung City has a population of 2,480,464 in 2019 with a Dependency Ratio of 38.29 (Statistics Bandung City, 2019). This means that every 100 productive people have 38 dependents who are 
no longer productive. To find out the population of Bandung City, here is a table of the percentage of Bandung City residents according to the age group in 2019.

Table 1 Percentage of Population by Age Group
\begin{tabular}{cc}
\hline Age Group & Percentage \\
\hline $0-14$ & 22,27 \\
\hline $15-64$ & 72,31 \\
\hline $65+$ & 5,42 \\
\hline
\end{tabular}

Source: Statistics Bandung City, 2019

From the table above, it is known that the largest percentage of age groups in Bandung is in the age range 16-64 years, which means there will be a significant increase in the number of elderly people in the future. This needs to be of concern to various parties because there is a potential vulnerability in the elderly, both from physical, social, mental, and spiritual aspects. This potential vulnerability can arise because the elderly do not have social security or health insurance in old age (Bahruddin, 2010).

The development of a governance paradigm in which the government is no longer the only actor in charge of public affairs opens greater opportunities for the elderly to get attention, not only by the government but also other stakeholders outside the government. Various stakeholders can work collaboratively to help the elderly achieve a good quality of life in old age, not only in terms of health and financial independence but also assistance that encourages social interaction to increase the happiness of the elderly. One of the things done in Bandung City is establishing elderly schools.

This elderly school seeks to provide informal education to the elderly to increase knowledge and behavior about health, increase the elderly happiness index, improve the quality of life and productivity and increase physical, psychological, social, and spiritual independence. Also, elderly schools encourage the elderly to have social interaction. This social interaction has positive benefits for the quality of life because the elderly will not feel lonely (Andesty and Syahrul, 2017; Samper, et al, 2017).

The establishment of this elderly school is in line with the mandate of Law No. 13 / 1998 that the elderly have the right to improve social welfare, including religious and mental-spiritual services, health services, job opportunity services, education and training services, ease of use of public facilities and infrastructure, ease of legal services, social protection, and social assistance. Also, education through elderly schools is useful for improving the quality of life because it can encourage independence and cognitive function in the elderly (Susanti and Livana, 2019). A similar opinion is from Indrayani and Ronoatmodjo (2018) that the factors that affect the quality of life of the elderly are education, work, and family support.

This elderly school is an initiation of Indonesia Ramah Lansia (IRL), Center of Family and Aging Studies (CEFAS) Universitas Respati Indonesia, and the government to create happy, dignified, healthy, independent, active, productive elderly. Then, this program also received a lot of assistance from the private sector and other elements of society. The collaboration is expected to optimize the functions of elderly school and produce higher benefits for the elderly. This study aims to describe collaboration in the elderly school program in Bandung City, by 
analyzing the driving factors for collaboration, the collaboration process, and the benefits of the collaboration.

Studies to improve the quality of life of the elderly are important considering that the elderly are a vulnerable group. Providing education for the elderly through elderly school is not widely available in Indonesia. Before Bandung City, Yogyakarta City already had an Elderly School, namely the Golden Geriatric Club. This elderly school was formed by the Budi Mulia Dua Yogyakarta Foundation to empower the elderly. Badriyah (2014) examined these elderly schools by exploring the context of the program, starting from the input, the process, to the output of the program.

In comparison, Indonesia's neighboring country, Thailand, also has a similar program, namely the Phayao Elderly School, the most successful elderly school in Thailand. Unlike the elderly school in Yogyakarta City, Phayao Elderly School was formed through a collaborative process (Whangmentukorn, 2012). Whangmentukorn's research (2012) shows that there are factors that encourage collaboration, namely the deteriorating health of the elderly and the increasing number of the elderly population. Also, there is a collaborative network between stakeholders that can support the elderly school. Then, another driving factor is the belief that this elderly school can boost the integrity and self-esteem of the elderly.

The research in this paper wants to describe collaboration in the elderly school program in Bandung City. The formation and implementation of elderly schools in Bandung City are carried out in collaboration between several stakeholders. It is interesting to know the differences in the collaboration of the elderly school program in Indonesia, especially in Bandung City compared to Thailand, with different governmental contexts and community cultures.

It is known that collaboration develops in open governance because there is the involvement of non-government stakeholders in making decisions or policies related to programs for the public (Ansell and Gash, 2008; Emerson, et al, 2011). From another point of view, collaboration can increase innovation and outcomes by creating opportunities for other elements to be involved (Edelmann, et al, 2012). The involvement of other elements in this public program is because the government often has various limitations. This is in line with what Ansel and Gash (2008) stated that collaboration is a response to the failure of policy implementation at the downstream level, high-cost policies, and complexity of regulations.

Collaboration is also often interpreted as the use of resources owned by stakeholders to solve public problems (UNCG Collaborative Capacities Working Group, 2012). This is done so that the burden of programs or activities to solve public problems can be shared. Then why do actors collaborate for results that tend to "benefit" other parties or the public?. Edelmann, et al (2012) stated that there are several reasons behind the willingness to collaborate, namely a sense of empathy, interest from actors, and the existence of reciprocity or benefits for actors.

In collaborating, at least three stages are carried out, namely identification of problems and opportunities, discussing strategies for problem-solving, and making collaborative action plans (Ratner, 2012). Thus, collaboration requires interaction and compromise, whether individuals, institutions, or other parties who are directly or indirectly involved (Haryono, 2012). Meanwhile, the success of 
this collaboration is supported by several things, namely the networked structure, commitment to common purpose, trust among the participants, governance, access to authority, distributive accountability/responsibility, information sharing, access to resources (Goldsmith and Donald, 2009).

Observing the above matters, collaborative governance has its complexities as an implication of the existence of many actors involved. Therefore, understanding collaboration certainly needs to pay attention to many aspects of it. There is one model that can help us understand collaboration, as presented by Ansell and Gash (2008) below.

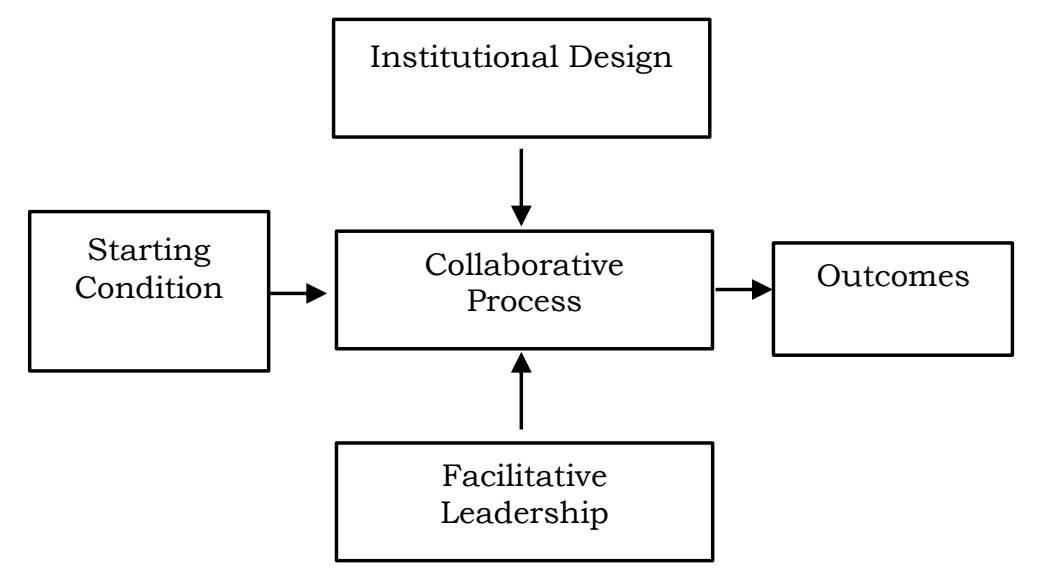

Figure 1 A Model of Collaborative Governance (Ansell and Gash, 2008)

Ansell and Gash (2008) suggest that there are important things in collaboration. Collaboration is based on the existence of causes or factors driving collaboration. Each actor involved in the collaboration certainly has their motives but they are put together to achieve a common goal. The more driving factors to achieve common goals, the greater will, and commitment to collaboration.

Also, the success of the collaboration process is influenced by other factors, namely how the roles of each stakeholder are regulated so that there is the legitimacy for what is done. The collaboration process is also determined by the leadership in the collaboration. Leadership is important in facilitating dialogue and building trust from stakeholders. These factors then produce outcomes or benefits, both for the target program group and for stakeholders.

Research on collaboration using the Ansell and Gash framework has been used by researchers, one of which is Ullah and Kim (2020) who researched collaborative governance in a community-based "Trophy-Hunting" program in developing countries. This program promotes a way related to the conservation of endangered animals. The analysis using this framework explains the starting conditions that encourage collaboration, things that support the collaboration process, and the outcomes that are generated from the collaborative program.

Reflecting on previous research, to understand collaboration in the elderly school program in Bandung City, the collaborative governance model from Ansell and Dash (2008) is quite relevant to be used as a framework. Returning to the importance of collaboration, collaboration as an alternative in governance is certainly not something that can be easily done. It becomes a challenge to create 
a strong and effective collaboration to achieve goals. Thus, studies on this collaboration need to be continuously developed, especially to produce an effective collaborative process with a high value of benefits.

\section{RESEARCH METHODS}

This study uses a descriptive research method using a qualitative approach. The choice of this method is based on a scientific method that is considered the most appropriate to reach, explain, and describe all problems in more depth related to collaboration in the elderly school program in Bandung City.

This study uses a framework from Ansell and Gash (2008) to identify and analyze the factors that encourage collaboration in the elderly school program in Bandung City, how stakeholders carry out the collaboration process, including things that encourage and hinder the collaboration process. Besides that, this research also wants to see the benefits of collaboration. By knowing these things, a conclusion will be drawn about important things in collaboration to increase the effectiveness of collaboration, both specifically in the elderly school program and in general other collaborative programs in Bandung City.

Research informants came from stakeholders in the elderly school program in Bandung City, including from Indonesia Ramah Lansia (IRL), Bandung City Government through Women's Empowerment, Child Protection, and Community Empowerment Office, and Sahabat Lansia (volunteers). Apart from interviews with informants, data was also obtained from various documents related to elderly school. Then, data analysis was carried out with four stages of activity, namely data collection, data condensation, data presentation, and drawing conclusions or verification.

\section{RESULTS AND DISCUSSIONS}

\subsection{Elderly School as a Collaborative Program}

Elderly schools try to adopt the concept of lifelong education where education does not stop until someone becomes an adult. This lifelong education becomes a necessity because humans need to adapt and live normally in the community. This lifelong education does not always have to go through formal educational institutions, but can also be done through informal education available in families and communities (Elderly School Practical Module, IRL).

In Bandung City, as a first step, four elderly schools were formed in four sub-districts, namely Sukajadi Sub-district, Antapani Sub-district, Ujung Berung Sub-district, and Cinambo Sub-district. This elderly school targets participants from the elderly with the age of 60 years and also pre-elderly with an age range of 45-59 years. This senior school is held once a month with 25-35 elderly participants per class. Learning activities are carried out through providing information, training, and educational games about health, socio-culture, religion. This elderly school uses the available space in the sub-district hall.

As an informal education institution, this elderly school has a curriculum prepared by Indonesia Ramah Lansia (IRL) and the Center of Family and Aging Studies (CEFAS). Each participant in an elderly school is also provided with a notebook as a learning tool for the elderly, as well as being used to measure the Elderly Happiness Index. The learning process is facilitated by elderly school instructors who have previously received training as instructors. In addition to 
learning activities, this senior school also provides health checks and provides nutritious food for the elderly.

From the explanation above about the activities in elderly schools, a lot of resources are needed to support the operation of the elderly schools, both in terms of human resources, infrastructure, and other supporting elements. The fulfillment of resources then carried out through the collaboration of stakeholders, including from government elements, namely the Bandung City Government through the Women's Empowerment, Child Protection, and Community Empowerment Office, Public Health Office of Bandung City with Public Health Center located in sub-district, Social Service Office of Bandung City, Agricultural Service Office of Bandung City, Creative Economy Office, Regional Elderly Commission, as well as local stakeholders such as sub-district heads and village heads. Besides, collaboration was also carried out with the National Population and Family Planning Board, BAZNAS West Java and Bandung City, hospitals, and clinics.

Also, there is a big role from non-government organizations, academics, and other elements of society, including Indonesia Ramah Lansia (IRL), Center of Family and Aging Studies (CEFAS) Universitas Respati Indonesia, and Sahabat Lansia (volunteers). Then, there is also the involvement of the private sector or entrepreneurs and communities who contribute to providing food for the elderly. This program opens the involvement of all parties who want to contribute to this elderly school program following their functions and abilities.

Elderly schools as one of the collaborative programs in Bandung City show that it is possible to involve various stakeholders in solving public problems, which in this case is related to elderly problems where the basic function was previously owned by the government. Through the involvement of stakeholders with the contribution of their resources, the elderly school program can be implemented.

\subsection{The Driving Factors for Collaboration}

The collaboration of stakeholders in the elderly school program in Bandung City does not just happen. Some factors can encourage these actors to contribute to elderly schools and of course, each actor can have different driving factors. There are at least three main motives as driving factors for collaboration in the elderly school program in Bandung, namely the same goals and interests related to empowering the elderly, having appropriate resources with their fields and functions, and getting benefits from their involvement.

As previously mentioned in the introduction, there are several main reasons for the existence of an elderly school in Bandung City. These reasons relate to the increasing number of elderly people with increased life expectancy, increased risk factors for degenerative diseases, decreased bodily function, emotions, and loneliness, and awareness regarding the need for prevention and guidance on health, spirituality, and social issues. Actors who have concern and interest in the issue of elderly empowerment are then encouraged to collaborate in the program. For example, Indonesia Ramah Lansia (IRL) as a non-government organization has a goal of creating an area friendly for the elderly with various programs related to the elderly. They contribute according to their fields and functions, including developing a model of informal education for the elderly. 
The issue of the elderly is also a concern of the Bandung City government by making Bandung as a city-friendly to the elderly. This can be seen from the efforts to formulate regional regulations that specifically address the fulfillment of the rights of the elderly in Bandung City. Also, Bandung City government pays attention to the elderly by forming a special field in Women's Empowerment, Child Protection, and Community Empowerment Office, namely the Protection and Fulfillment of the Rights of the Elderly. Then, to show seriousness in fulfilling the rights of the elderly, there are already 20 public health centers in Bandung City that are elderly-friendly. Other attention is also given through the Sahabat Lansia program that has been around since 2017 to assist in elderly activities, including providing free food, sports, recitation, and health checks. This Sahabat Lansia consists of 5-10 people who are volunteers in each subdistrict.

Another example is the involvement of academics who are members of the Center of Family and Aging Studies (CEFAS) Respati Indonesia University, a center for studies concerned with elderly issues and provides support for elderly school programs according to their capacity. Then, the private sector or entrepreneurs and community are encouraged to care for the elderly through Corporate Social Responsibility and charity. Another element in Bandung City which has a cross-section of objectives and scope of activities related to the empowerment of the elderly can contribute to the elderly school program.

The involvement of stakeholders in the elderly school program is also encouraged by the benefits, including achievements or awards, tasks related to elderly empowerment can be carried out, benefits for the elderly, and even gaining happiness because they are useful for the elderly. Thus, the three factors described above are the main factors driving stakeholders to collaborate in the elderly school program.

\subsection{Collaborative Process of Stakeholders}

In the previous discussion, it was stated about the driving factors that make collaboration between stakeholders possible in the elderly school program. Furthermore, there is a collaborative process of stakeholders which begins with a dialogue. The dialogue process was initiated by the actors who were the initiators of this program, namely Indonesia Ramah Lansia (IRL), the Center of Family and Aging Studies (CEFAS) Universitas Respati Indonesia, and the Bandung City government. After that, information about the elderly school program was also shared with other actors with interests related to the elderly in Bandung City, so that these actors were willing to join. This dialogue is carried out to reach an agreement related to elderly schools, following the functions and duties of each actor.

In the collaboration process, there are also efforts to involve the private sector in this program, especially in the Sibulan (Nasi Bekal Sehat Untuk Lansia) activity. This activity aims to fulfill nutrition for the elderly by providing healthy food. This involvement of the private sector is carried out through dialogue with proposals submitted by Sahabat Lansia to the private sector that have Corporate Social Responsibility programs. Also, various other communities contribute to procurement and fulfill other needs. The whole process then becomes a meeting point for stakeholders and creates shared value to create a happy and empowered elderly in Bandung City. 


\subsection{The Benefits of Collaboration}

The collaborative process carried out by the actors has a common goal, namely the success of the elderly school program. As stated in the previous section, the elderly school aims to empower the elderly to be happy and prosperous in their old age through increasing the happiness index, improving quality of life, increasing productivity, and independence of the elderly. Through the collaboration of various stakeholders, it is hoped that it can optimize the positive impact of the program for the elderly.

Apart from having benefits for the elderly, the existence of an elderly school program also indirectly has benefits for collaborating stakeholders. For example, the elderly school is an actualization forum to support the goals of the Indonesia Ramah Lansia (IRL), namely to create an elderly-friendly area. Through the elderly school program, Indonesia Ramah Lansia (IRL) received an international award in 2020, namely the Asian Health and Welfare Initiative. Other actors, for example from the Center of Family and Aging Studies (CEFAS), University of Respati Indonesia, the elderly school program is a place to conduct studies and community service for scientific development related to the elderly.

The Bandung City Government also indirectly benefits from the existence of an elderly school, namely helping to make the development program related to the elderly in Bandung City successful. Furthermore, it can foster the public trust that the government has a concern for the elderly as vulnerable people and need attention. Then, with the elderly school program, the Bandung City government can establish relationships and cooperation with various parties as a step to pave the way for collaboration in other programs.

In the process of collaboration in the elderly school program, other actors who are willing to collaborate have specific missions and goals that are in line with the elderly school program. What is important to encourage stakeholder collaboration is to start with a dialogue process. This process can form a belief that the program can be carried out responsibly and yield benefits for the elderly. With this trust, stakeholders will not hesitate to contribute according to their functions and duties.

\section{CONCLUSION}

The elderly school program in Bandung City as a collaborative program is expected to create empowered elderly people. This program is driven by various problems related to the elderly in Bandung City. Collaboration carried out by stakeholders is driven by several factors, including the same goals and interests related to empowering the elderly, having appropriate resources with their fields and functions, and getting benefits from their involvement. Then, the collaborative process begins with a dialogue to build trust among stakeholders. This can lead to a commitment to contribute to this program. Collaboration in the elderly school program is not only beneficial for the elderly but also for the actors involved. This is also a driving factor for collaboration.

\section{REFERENCES}

Andesty, D and Dyahrul, F. (2018). Hubungan Interaksi Sosial dengan Kualitas Hidup Lansia di Unit Pelayanan Terpadu (UPTD) Griya Werdha Kota Surabaya Tahun 2017. The Indonesian Journal of Public Health, Vol. 13., 
No.2.,

Hal.

171-182.

DOI:

http://dx.doi.org/10.20473/ijph.v13i2.2018.171-182.

Badriyah, F. (2014). Skripsi: Program Sekolah Lanjut Usia Golden Geriatric Club di Yayasan Budi Mulia Dua Yogyakarta. Universitas Negeri Yogyakarta.

Bahruddin. (2010). Pengarusutamaan Lansia dalam Pelayanan Sosial. Jurnal Ilmu Sosial dan Ilmu Politik (JSP), Vol. 13., No.3., Hal. 1-13. DOI: https://doi.org/10.22146/jsp.10953.

Edelmann, N. et al. (2012). Collaboration for Open Innovation Processes in Public Administrations. Empowering Open and Collaborative Governance. Page 21-37. DOI: 10.1007/978-3-642-27219-6_2.

Emerson, K, etc. (2011). An Integrative Framework for Collaborative Governance. Journal of Public Administration Research and Theory. Page: 1-30. DOI:10.1093/jopart/mur011.

Goldsmith, S., dan Donald F. K. (2009). Unlocking The Power Of Networks: Keys To High- Performance Government. Brookings Institution Press: Washington, D.C.

Haryono, N. (2012). Jejaring Untuk Membangun Kolaborasi Sektor Publik. Jurnal Jejaring Administrasi Publik, Th IV. No. 1.

Indrayani and Ronoatmodjo, S. (2018). Faktor-faktor yang Berhubungan dengan Kualitas Hidup Lansia di Desa Cipasung Kabupaten Kuningan Tahun 2017. Jurnal Kesehatan Reproduksi, Vol.9, No.1., Hal. 69-78. DOI: 10.22435/kespro.v9i1.892.69-78.

Ratner, B.D. (2012). Guidance Note AAS-2012-27: Collaborative Governance Assessment. Malaysia: Research Program on Policies, Institutions, and Markets.

Samper, T. et al. (2017). Hubungan Interaksi Sosial dengan Kualitas Hidup Lansia di BPLU Senja Cerah di Provinsi Sulawesi Utara. Jurnal Keperawatan, Vol. 5., No.1.

Seftiani, S. (2018). Menelaah Program Lansia di Indonesia. Available online: https://kependudukan.lipi.go.id/en/population-study/36-kesehatanmasyarakat/532-menelaah-program-lansia-di-indonesia.

Susanti, Y dan Livana PH. (2019). Peningkatan Kemandirian dan Fungsi Kognitif Lansia Melalui Pendidikan Kesehatan tentang Perkembangan Psikososial Lansia. Jurnal Keperawatan, Vol 11., No.3., Hal 155-162.

Ullah, I dan Kim, D. A. (2020). A Model of Collaborative Governance for Community-based Trophy-Hunting Programs in Developing Countries. Perspect Ecol Conserv. DOI: https://doi.org/10.1016/j.pecon.2020.06.004.

Whangmahaporn, P. (2012). Collaboration of Public Services of Phayao Elderly School, Northern Thailand. Journal of Government and Politics. Vol.3, No.2, Hal. 284-296. DOI: http://dx.doi.org/10.18196/jgp.2012.0015. 